\title{
The Royal Decrees Of The NeW KingdoM (\&)
}

\section{Heba Mohamed Omar Mohamed \\ Faculty Of TOURISM ANd Hotels, Minia University, Egypt}

\begin{abstract}
This study exploration proposes to clarify the imperial pronouncements in the New Kingdom.

The significance of this examination comes from the way that the state in antiquated Egypt was presumably kept running by the imperial announcements which thought about a rich report to know the different perspectives in Ancient Egyptian human progress, focuses on the regal control on organization, the board and undertakings of the nation including the direction exercises, actualize administrative measures notwithstanding uphold sanctions against socially unsafe conduct and infringement.
\end{abstract}

KEYWORDS: The Royal Command, Administration Decrees, Protection Decrees, Punishment Decrees.

(*) This paper is a part of a dissertation submitted in partial fulfillment of the requirements of master degree in Tourist Guidance, Faculty of Tourism and Hotel Management, Minia University, "The Royal Decrees in the Political and Administrative Life in Ancient Egypt till the End of the New Kingdom: "Historical Study" under the supervision of Prof. Dr. Sherif El Sabban, Minia, 2019. 


\section{INTRODUCTION}

In Ancient Egypt, law appears to have been a part of organization to accomplish equity among people; Egyptian law was basically founded on a sound judgment perspective of good and bad dependent on the idea of Maat which spoke to truth, request, equalization and equity known to man, the ruler's obligations in guarding Maat. ${ }^{1}$ The pharaohs as living divine beings were the source and agents of equity connected the idea of equity between their subjects. The Kings issued a legitimate request having the power of law to directing the status and conduct of people as any order mirrored the divine beings claim direction, and his power was universal reflecting his authoritative capacity and deal with any aspect of Egyptian society. ${ }^{2}$

Each old society required law to fortify it's inside union, by control exercises and execute administrative measures and to implement sanctions against socially unsafe conduct and infringement. ${ }^{3}$

The Egyptian law is the most established legitimate framework; the lord was the sole lawmaker. The primary proof of a pronouncement goes back to fourth Dynasty exception announcement of Shepseskaf issued to support the domain and staff of the pyramid of Menkaurea, trailed by a genuine of illustrious declarations including Exemption orders, security orders, Endowment proclaims notwithstanding the organization of the nation.

\section{DISCUSSION}

The New Kingdom was one of the most prosperous periods of ancient Egyptian history. This is the time of imperial Egypt that extended beyond the former borders to create an empire. It is the most popular era in Egyptian history. The king headed a number of administrative bodies, which witnessed, from the New Kingdom onwards at least, a relative independence from each other. The royal orders issued in the form of decree laws, ${ }^{4}$ then, this order would be

\footnotetext{
${ }^{1}$ N. Shupak (1992) A new source for the study of the judiciary and law of ancient Egypt: "The Tale of the Eloquent Peasant", JNES 51, 15.

${ }^{2}$ P.Vernus, (2013) "The royal command (wd-nsw): A Basic deed of executive power", in Ancient Egyptian Administration, Brill, 315.

${ }^{3}$ E. Otto (2007), "Law and Ethics", Ancient Religions, Cambridge, 85- 94.

${ }^{4}$ A monumental inscription sanctioned by the king that assigned legal, economic, and political provisions usually to some cultic institution (i.e.
} 
implemented by a bureaucratic regime, which became necessary to rule the country. Thus, royal decrees issued to grant the religious institutions some privileges to protect the temple properties, staff and workers from being accused by certain compulsory state labour obligations, as known since the Old Kingdom. Thus, it concerned with the organization of the public economy not a social measure. ${ }^{5}$

\section{Examples OF THE Royal Decrees During THE NeW KINGDOM}

\section{Great EDICT OF HoREMHEB}

King "Horemheb" considered as one of the most important legislators in history. His legislations regarded a civil rather than their contemporary religious decrees. His legislations intended, primarily, to protect the public freedoms and rights. He also emphasized the concept of public posts as a means to serve citizens rather than overpowering them. Horemheb's decree issued to protect and regulate the entire land. ${ }^{6}$

The fragmentary text inscribed on the largest stela that made of dark sand stone ever found in Egypt, which established at the foot of the tenth pylon at Karnak temples (fig.1 )outlining his new laws that designed to bring peace and harmony back to Egypt. The inscription is in very bad condition without any completed lines, despite missing the greater part of the hieroglyphic text, the left gave us much interesting information. There is another copy of the edict at Abydos but is damaged, as well.

\section{HOREMHEB'S DECREE CONSISTS OF FOUR PARTS}

\section{THE FIRST PART}

Introduction, Lines, 1-13, that contain the titles and expressions of praising for Horemheb.

temple, chapels,...), in addition to promoting religious bonds between the ruler and the associated deity or locality; P. Vernus, The royal command (wd-nsw), 259-335.

${ }^{5}$ A. Spalinger (1991), "Some Revisions of Temple Endowments in the New Kingdom", JARCE 28, 21-39; J. M. Galán (2000), "The Ancient Egyptian Sed-Festival and the Exemption from Corvee", JNES 59, 256- 264.

${ }^{6}$ M. Muller (1906),"Decree of administrative reforms by king Har-em-heb", in, Egyptological Researches,1, 58: J., Kruchten,(1981) Le Decret d'Horemheb, Bruxelles. 


\section{THE SECOND PART}

Legal part, lines 14-3 Left. which concern with different cases of injustice including-Enactment against, taking away the transporting vessels that used for delivering dues, enactment against ship-owners whose cargoes robbed, enactment against interfering with the delivery of dues forthe harem and divine offerings, enactment against requisitioning " $K t$ " plants and the appropriation of the services of privately owned slaves, enactment against looting of farms for hides with a clause in favour of taxpayers, enactment against extortion and corruption in the administration of the revenue, enactment against the unlawful collection of "sm" herbs, the unlawful collection of cereals, vegetables, etc., enactment against some other kinds of encroachment as well as enactment against the unlawful appropriation of slave labour.

The edict outlines very harsh punishments to those who were found guilty of corruption. The punishment included unlawful requisitioning of boats and slaves, illegal taxation, theft or cattle hides, fraud in assessing lawful taxes and extortion of local mayors by officials. ${ }^{7}$ The exemplary punishments to be imposed on guilty parties, such as facial mutilation "cutting off the nose" followed by exile to the northern eastern frontier zone of Tjaru " the place that devoted for various crimes and mutilated offenders and its remains form the Tell el-Habwa near Qantarah on the east side of the modern Suez canal". 8

\section{THE THIRD PART}

An administrative part, Lines 3, left- 6 or 7, right, included a section describing the composition of the central and local judicial courts by establishing (great) knbt- courts in the two great cities of Upper and Lower Egypt (Thebes and Memphis). Thus, Horemheb did not have time to oversee each court case individually, so it was necessary to appoint deputies and viziers to work on his behalf. ${ }^{9}$ Horemheb wanted to stamp down on all wrong doings in order to bring Egypt back to the laws of Maat.

\footnotetext{
${ }^{7}$ K.Pfluger (1946) "The Edict of king Haremheb", JNES 5, 260-268:A. Dodson (2000), Monarchs of the Nile, $2^{\text {nd }}$ edition, Cairo- New York, 116117.

${ }^{8}$ W. Helck (1955) "Das Dekret des Koenigs Haremheb", in ZAS 80, 118; B. Kemp (2006) Ancient Egypt: Anatomy of a civilization, $2^{\text {nd }}$ edition, 25.

${ }^{9}$ T. Tyldesley (2000), Judgment of the Pharaohs, London, 31.
} 
Knbt- courts were mainly social groups of individuals who functioned like a municipal council, representing a local administrative organization with wide ranging authority to enforce governmental orders and assisting the higher government in exacting any taxes due from the citizens, and responsible for running all kinds of common affairs in their localities (without remuneration). $\mathrm{He}$ reorganized the law-courts and the state workforce, including the tomb-builders village of Deir el-medina that was abandoned during the Amarna period when it suffered from fire damage; it was rebuilt within an extended town wall. Knbt -courts involved temple priests (hm-ntr, wcb ) and mayors (h3ty-c) and this reflected the social meaning of his policy that only the well-born persons who rise to the important positions in the society and administration and he reorganized the clergy of the country unlike Akhenaten who rise the low-birth to the important positions in the society and administration. Horemheb limited the powers held by the priesthood. On the other hand, he gave them the power of legal judges, this emphasized that once again, the law of Maat was to be obeyed and as the priests were servants of the gods, they were essentially doing the work of the gods, so that, the crimes of the people were judged by the god. moreover, these judges were thenceforth received salaries, evidently in order to make it less necessary for them to take bribes regardless of their religious posts by exempting them from taxes of gold and silver :meaning that they kept all their income, and to live in proper style. Horemheb was aware that some might still be corrupt, so he punished them. In order to keep a close eye on the officials, listen to their grievances and reward them for their loyalty. ${ }^{10}$

Other clause states the relationship between the king and his army officers by establishing honest loyal and high trained armed forces in order to implement his changes by promoting men into higher positions for their skills and ambitions.

The Fourth PART: The conclusion, lines 6 or 7 , right -9 right.

EVENTUALLY, Horemheb was proceeding resolutely to put an end to many administrative abuses by military and officials who weren't infrequently violating social justice, who rebuilt international links, achieved peace, restored religion, law, economy, and bring Egypt back to the glorious place, one protected by the gods, safe from

\footnotetext{
${ }^{10}$ S. Allam (1991) "Egyptian Law Courts in Pharaonic and Hellenistic times", JEA 77, 109-121; A. Schafik (2000), "The Tax Exemption of Horemheb", in Egyptology
} 
crime, free of corruption and abundant in food. ${ }^{11}$ It learn how deal with the restoration which embodied revolutionary features in the traditional scheme. ${ }^{12}$ Horemheb published his decree in the great temple of Amun-Re at Karnak, and another fragmentary copy at Abydos. This reflected that he published the edict throughout Egypt, to know all the people "in the remote regions as well as in the cities" the law of Horemheb, to illustrate the importance of the place as well as the importance of the decree itself. It believed that it is some sort of propaganda that worked to shore up political and spiritual support for all manner of pharaonic activity. ${ }^{13}$

\section{NAURI DECREe OF SETI I}

The decree of Seti 1 was a document published by Seti in the fourth year of his reign (fig. 2), it was proclaimed on behalf of the doers at the holy city of Osiris, where the king was in the process of making his great mortuary complex at Abydos. The only known copy of the decree is carved on a cliff at Nauri, between the $2^{\text {nd }}$ and $3^{\text {rd }}$ cataract, in Nubia.

Seti I added a legal portion, contains injunctions concerning infringements against the property and personnel of the cult of Osiris, in the form of public administrative laws issued for the internal development of Egypt in the Nineteenth dynasty and consolidate his economic control over the region by citing the infractions such as the illegal acquisition of servants or property belonging to the funerary estate ; the misappropriated of goods and materials sanctified for the temple personnel ; and criminal trespass . those guilty of crimes of this sort were to be punished with beating, accompanied by the confiscation of property and the loss of the offender's free status . However, in cases of selling an animal designated as an endowment to the estate of Osiris, the miscreant was liable to death by impalement. ${ }^{14}$

${ }^{11}$ C. Booth (2012) The Forgotten Pharaoh, Chalford Amberley, 120.

${ }^{12}$ K. Pfluger, "The Edict of king Haremheb, 268.

${ }^{13}$ M. Bunson (1991) Encyclopedia of Ancient Egypt, New York, 171.

${ }^{14}$ Gardiner, A,(1952), "Some Reflection on the NauriDecree", in, JEA, 38 , pp.24-33: W. F. Edgerton (1947), "The Nauri Decree of Seti I: A translation and Analysis of the legal portion", JNES VI, 219-230; S. Theodorides, (1971), The Concept of Law in Ancient Egypt, in the Legacy of Egypt, ed., J.R. Harris, Oxford, 291-322:F. L. Griffith(1927), "The Abydos Decree of Seti 1 at Nauri" in JEA 13, 200-208, Pls. XL-XLIII ; A. David,(2006), 


\section{LINES 30-42}

" His Majesty has commanded to cause that the House of Millions of Years of the King of Upper and Lower Egypt, Menmaatre (Seti I), "The Heart Is at Ease in Abydos," to be protected on water (and) on land throughout the nomes of Upper (31) and Lower Egypt,

In order to prevent wrong being done to "any person belonging to the Foundation, who is in (the) whole land, (whether) man (or) woman,

In order to prevent wrong that being done to any goods belonging to (32) this estate (pr) which are in (the) whole land.

In order to prevent any person belonging to this estate (pr) [being taken] by capture from (one) district for (another) district by corvee (or) by forced labour for plowing (or) by forced labour for harvesting by any viceroy, (33) any commandant, any mayor, any agent, (or) any person

[Sent on] mission [to] Kush,

In order to prevent their boat (im) being detained on (the) water by any patrol.

In order to prevent any wrong that being done to any fields of the (34) Foundation in rural districts [- - - - ] by any viceroy, any commandant, any agent of (the) House of Agents of the King's Estate (or any) person sent on mission to Kush.

In order to prevent cattle, (35) asses, swine, goats, (or other) animals belonging to the Foundation being taken by robbery or by way of liberty by any viceroy, any commandant, any mayor, (36) [any] charioteer, any stable [-chief], any chief of Nubians, [any] agent of the King's Estate, any person sent on mission to Kush.

In order to prevent wrong that being done to any catcher belonging to the Foundation (37) on his trapping marshes, on his fishing waters, (or) on fields which he has -ed.

In order to prevent any fisherman belonging to the Foundation being driven (38) from"1 his fishing-pools which are in the whole land of Kush, by any viceroy, any commandant, any mayor, any agent belonging to the whole land of Kush,

In order to prevent wrong being done to any personal of the (39) Foundation who are in the land of Kush, men (or) women, guardians of fields, agents, beekeepers, cultivators, gardeners, vintners, (40) bargees, packers, foreign traders, (the) staff of gold washing, carpenters', (or) anyone who carries on his occupation in the Foundation.

Syntactic and Lexico - Semantic aspects of the legal register in Ramesside royal decrees", GOF 38, Wiesbaden, 17-107. 
But they shall be (41) privileged and protected while every man of them carries on his occupation that is carried on in the Foundation, without letting them be interfered by any viceroy (42) of Kush. Any commandant, any magistrates, any charioteer, any stable-chief, any standard-bearer, any soldier of the army (or) any person sent on mission to Kush". 15

Seti 1 set a decree to look after the workers of the house of Osiris and to force fully protect the estates of the temple as boat fields, livestock, fishers and fowlers, as well as a wide range of welldeveloped productive activities such as wine growing gardening, beekeepers, gold washing, and other temple personnel, in question from other institutions, which might demand tax from them. ${ }^{16}$ In addition, it is outlining a series of possible crimes against persons and property belonging to the foundation with specific punishments for the offenders.

The other part of the Nauri Decree of concern, lines 70-82

"(70) Punishment shall be done to him by beating him with two hundred blows and exacting (?d) the animal (71) belonging to the Foundation from [him], (together with) a penalty at the rate of one hundred to one.

Likewise the one who (72) shall be found taking any animal belonging to the Foundation.

Punishment shall be done (73) to him by cutting off his nose (and) his ears, he being put as a cultivator in the Foundation, (74) - - - and putting his wife (and) his children as serfs of (the) steward of this estate.

Now as to any keeper of cattle, any keeper of hounds, (or) any herdsman (75) belonging to the Foundation who shall sell any animal belonging to the Foundation (76) to another; likewise the one whol shall cause it to be offered on another list and not to be offered (77) to Osiris its lord in the Foundation.

Punishment shall be done to him by casting him down, placing him on (78) top of a stake, and dedicating [ his] wife, his children, (and) all his property to the Foundation (79) and exacting (?d) the animal from the one to whom he shall have [given] it. Together with a penalty (in favour of) the Foundation (80) at the rate of one hundred to one.Now as to any person who is in (the) whole land (81) who shall drive off [any] herdsman belonging to the Foundation from' his pasturage.(82) Punishment shall be done to him by beating him with one hundred blows (and) five pierced wounds." $" 17$

\footnotetext{
${ }^{15}$ W. F. Edgerton, "The Nauri Decree of Seti I", 221- 222

${ }^{16}$ A. Gardiner, Some Reflection on the Nauri Decree, 26.

${ }^{17}$ W. F. Edgerton, "The Nauri Decree of Seti I", 224-225
} 
This part of the text reflected the Egyptian justice which was traditionally marked by its human treatment of criminals, from the first legal text in the Old Kingdom through the Middle Kingdom till the New Kingdom, the punishments for most crimes involved beating, cutting off nose and ears, removal from office, forced labour, in some cases the impalement. ${ }^{18}$ Moreover, these penalties are specified through the crime, not through the social status or administrative position of the criminal.19 The main aim of the decree was not to weak the government but to control the behaviour of its officers, to be less capricious. ${ }^{20}$

\section{KANAIS DECREE}

It is inscribed in the temple of Seti I at Kanais ${ }^{21}$ in the Wadi Mia or Wadi Abbad near the eastern desert gold mines, published in his $9^{\text {th }}$ year of his reign, Such an inscription offers an interesting perspective on the nature of kingship and its authority in the New Kingdom, as well as defines the role of this small temple in the cult to the gods and the king in the eastern desert, it preserves a royal decree that establishes legal resolutions assigned to the temple and its personnel as well as protected the personnel of the mortuary temple of Seti I at Abydos who engaged in mining, washing and transporting gold from the eastern desert. This decree includes an order of exemption, protection and divine punishment to the offenders. ${ }^{22}$

${ }^{18}$ A. J,van Loon (2014), Law and Order in ancient Egypt, The Development of Criminal Justice from the Pharaonic New Kingdom until the Roman Dominate, MA, thesis, Leiden university, 6-20.

19D., Lorton(1977), "The Treatment of Criminals in Ancient Egypt", in: JESHO 20, 27.

${ }^{20}$ W. Edgerton, The Nauri Decree of SetiI, 230.

${ }^{21}$ The rock-temple with its well and its associated personnel functioned as an independent administrative institution for gold extraction and quarry exploration in the wadi area and became a prominent station in the route from Edfu to Berenice, on the southern Red Sea coast, in addition to support the construction of his mortuary temple at Abydos and other buildings at Thebes, S. Schott (1961), Kanais. Der Tempel Sethos I. imWadi Mia, (Nachrichten der Akademie der Wissenschaften in Göttingen, Philologisch- historischeklasse 196I/6), Göttingen, 168-174; P, Brand (1998), The Monuments of Seti I and their historical significance: epigraphic, art historical and historical analysis, Ottawa: National library of Canada, 315- 318.

${ }^{22}$ B. Gunn, \&A. H. Gardiner(1917), New Readings of Egyptian Texts, JEA, 4, 241- 250; H. Sottas, (1913), La préservation de la 
The inscription located on the western section of the north wall in which the legal stipulations for the temple of Kanais are established (fig.3). This section constitutes the opening of the royal decree, in which the king refers to his royal forefathers and calls for their support then, in the central part of the inscription Seti I praising those who obey his stipulations and then issuing his threat to whomever failures to do so. Once more, the threat is used as a magical mechanism that enhances the assertions of his legal stipulations and safeguards the whole decree from amendment.

The text reads:

"(The) King of Upper (and) Lower Egypt, Menmaatre, Son of Re, Seti I Merenptah, says to his fathers, all the Upper Egyptian kings, the Lower Egyptian kings, rulers of (the) people".

" (...) it is concerning the affectation of/ while posting my staff of mine-water transporters for gold- washers to my temple, to place them for (the) supply to my house [in Abydos, for the delivery of gold? To] my chapel,

Other parts of the text concern a royal threat to future successors and officials who removed the temple personal to place them in another foundation:

"As for any king who shall overthrow any of my plans and says: 'The lands are under my authority and they are mine as they were his', (this is) a bad thing in the opinion of the gods. See, he will be accused in Heliopolis, they are the (divine) tribunal [...] they will defend their property. They will become red as fiery flame, they shall burn up their flesh, those who fail to listen to me, and they will consume whoever upsets my plans, to cast him (down) on the slaughtering-block of the Netherworld. I have said these (things) to you; so let him who is free of his crime take him, but indeed, as for another who is slippery-hearted, it is the Ennead of gods who will deal with him"

"As for any official who shall encourage this idea in his master, to remove personnel, to place them in some other endowments, according to the manner of an evil witness: he is destined to the fire,

propriétéfunérairedansl'AncienneEgypte. Avec le recueil des formulesd'imprécation,Paris: champion, 128- 132; C. Sander-Hausen, (1933), HistorischeInschriften der 19. Dynastie. I, Bae 4, 25-29; A., Théodoridès, (1972), Mettre des Biens sous les pieds de quellqu'un, Rde 24, 188- 192. 
which shall burn up his body with flames and shall devour his limbs, because his Majesty has done these (things) for their essence (lit. K3), the gods of my temple". ${ }^{23}$

Severe physical punishments lay ahead for disobedient kings ${ }^{24}$ and insubordinate officials who showed no respect for the king's provisions. The threat offers the most remarkable description of punitive undertakings against violators, in this decree there is no reference to filial rejection, beating, or removal from the royal office, but they might be taken for granted at seeing the consequences of disobedience for the royal persona and his ka. Corporeal punishment in both royal and non-royal cases included the total annihilation of the individual by executing him and burning his body. ${ }^{25}$

\section{CONCLUSION}

Every ancient society needed law to strengthen its internal cohesion, based on a common sense view of right and wrong, which represented truth, order, balance and justice in the universe. The king's duties in defending Maat through detailed legal edicts that considered as an expression of the royal will, regulating the status and behaviour of individuals.

By the New Kingdom, The gods received piles of offerings, rituals and celebrated by great number of priests. To maintain this religious establishment, large parts of Egypt were consecrated to the temples. It is shown that these temples owned as much as third of the arable surrounding lands and were exempted from taxes. Even the people in their employment, were protected by law against impressment, the employment of the royal decrees addressed to any transgressor of the king's resolutions played a significant role, enhancing the authority of the official document beyond the capacity of legal agencies.

The best preserved and a good example for all the decrees that regulate the country is the great edict of Horemheb, who intended to

\footnotetext{
${ }^{23}$ Schott, Kanais. Der Tempel Sethos I. Im Wadi Mia,151-155, Pl.16-17; B. Gunn, \&A. H. Gardiner, New Readings of Egyptian Texts, 246- 249.

${ }^{24}$ Seti I warns his future successors of his determination to preserve his authority as a great ruler, consolidating his dominion even upon the future members of his own lineage, and ruling over time

${ }^{25}$ A. Leahy, (1984), 'Death by Fire in Ancient Egypt', JESHO 27/2, 199206; S.Morschauser, (1991), Threat-Formulae in Ancient Egypt. A Study of the History, Structure and Use of Threats and Curses in Ancient Egypt Baltimore, 185- 188.
} 
stamp out widespread bribery and corruption to put an end to many administrative abuses by military and officials who were not infrequently violating social justice, Sometimes the royal decrees issued to consolidate the economic control over the region by pronouncing the punishments as Nauri- kanais decrees of Seti I .These penalties are specified through the crime, not through the social status or administrative position of the criminal. The main aim of the decree not to weak the government but to make the behaviour of its officers less capricious. From a political point of view, the royal decrees considered as a kind of redefinition of responsibilities within the same governmental structure.

\section{REFERENCES}

Allam, S., (1991) "Egyptian Law Courts in Pharaonic and Hellenistic times", JEA 77, 109-121

B. Gunn, \&A. H. Gardiner (1917) New Readings of Egyptian Texts, JEA, 4, 241-251.

Booth, C. (2012), The Forgotten Pharaoh, Chalford Amberley.

Brand, P., (1998) The Monuments of Seti I and their historical significance: epigraphic, art historical and historical analysis, Ottawa: National library of Canada.

Bunson, M., (1991),Encyclopedia of Ancient Egypt, New York.

Dodson, A. (2000), Monarchs of the Nile, 2nd edition, Cairo-New York.

Edgerton, W. F. (1947), "The Nauri Decree of Seti I: A translation and Analysis of the legal portion", JNES VI, 219-230.

Galán, J. M. (2000),"The Ancient Egyptian Sed-Festival and the Exemption from Corvee", JNES 59, 256-264.

Gardiner, A, (1952),"Some Reflection on the Nauri Decree", in, JEA, 38, pp.24-33

Griffith, F., (1927),"The Abydos decree of Seti I at Nauri", JEA, 13, 207-208.

Griffith,F. L, (1927), "The Abydos Decree of Seti 1 at Nauri" in JEA 13, 200-208, Pls. XL-XLIII.

Helck, W, (1955),"Das Dekret des Koenigs Haremheb", in ZAS 80 .

Kemp, B.,(2006), Ancient Egypt: Anatomy of a civilization, 2nd edition.

Kruchten, J.,(1981),Le Decret d'Horemheb, Bruxelles.

Leahy, A., (1984), 'Death by Fire in Ancient Egypt', JESHO 27/2, 199-206 
Lorton, D., (1977),"The Treatment of Criminals in Ancient Egypt", in: JESHO 20, 3-42.

Morschauser, S., (1991) Threat-Formulae in Ancient Egypt. A Study of the History, Structure and Use of Threats and Curses in Ancient Egypt, Baltimore.

Muller, M.,(1906) "Decree of Administrative Reforms by king Harem-heb", Egyptological Researches, 1.

Otto, E, (2007) "Law and Ethics", Ancient Religions, Cambridge.

Pfluger,K., (1946), "The Edict of king Haremheb", JNES5,260-268

Sander-Hausen, C., (1933) Historische Inschriften der 19. Dynastie. I, Bae 4, 25-29

Schafik, A., (2000), "The Tax Exemption of Horemheb", in Egyptology at the Dawn of The Twenty First Century", Cairo, Volume 2.

Schott, S., (1961) Kanais. Der TempelSethos I. imWadi Mia, (Nachrichten der Akademie der Wissenschaften in Göttingen, Philologisch- historischeklasse 196I/6), Göttingen.

Shupak, N., (1992), A new Source for the Study of the Judiciary and Law of Ancient Egypt: "The Tale of the Eloquent Peasant", JNES 51, 1-18.

Sottas, H.,(1913),La préservation de la propriétéfunérairedans l'Ancienne Egypte: Avec le recueil des formules d'imprécation, Paris: champion.

Spalinger, A,(1991),"Some Revisions of Temple Endowments in the New Kingdom", JARCE 28, 21-39.

Théodoridès, A.,(1972),Mettre des Biens sous lespieds de quellqu'un, Rde 24, 188-192.

Theodorides,S., (1971), The Concept of Law in Ancient Egypt, in the Legacy of Egypt, ed., J.R. Harris, Oxford, 291-322

Tyldesley, T.,(2000), Judgment of the Pharaohs, London.

Van Loon, A. J, (2014), Law and Order in ancient Egypt: The Development of Criminal Justice from the Pharaonic New Kingdom until the Roman Dominate, MA- Thesis, Leiden university.

Vernus, P, (2013) "The royal command (wd-nsw): A Basic deed of executive power", in Ancient Egyptian Administration, Brill. 


\section{FIGURES}

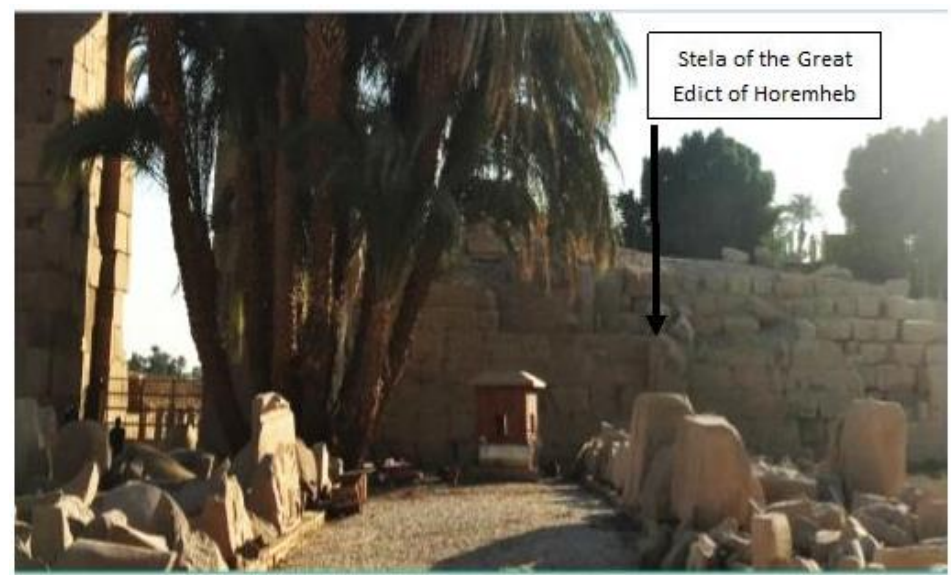

Fig 1 Stela of Horemheb at the foot of the tenth pylon at Karnak temples, Photo by the researcher

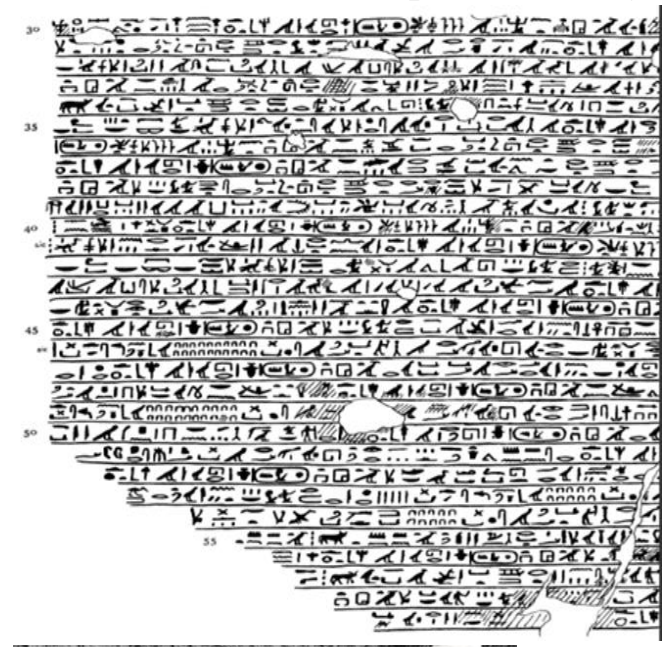

Fig 2 Part of Nauri decree F, Griffith, The Abydos Decree of Seti I at Nauri

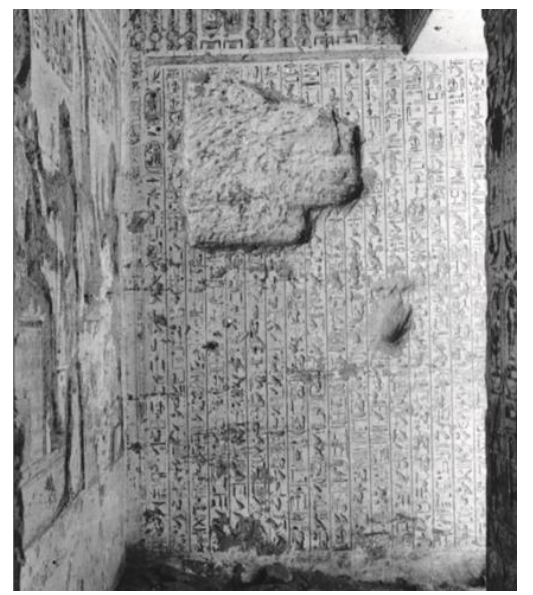

Fig 3 Kanais decree in the western section of the north wall at Kanais temple

Schott, S., Kanais. Der Tempel Sethos I. imWadi Mia 